\title{
Opening learning spaces for business interns - some insights derived from the PEARL project
}

\section{Annette Ostendorf}

Business internships in the context of Austrian colleges for higher vocational education (upper secondary level, ISCED 4a/5) are well established and linked to the curriculum. However, not much is known about the interns' learning contents and processes within such working-learning arrangements, particularly from the interns' perspectives. Therefore, in the PEARL project, learning in internships is investigated in a very specific way. The interns are involved as junior researchers playing an active role in collecting and interpreting data. They act-after some preparation by a researcher team at Innsbruck University - like auto-ethnographic researchers in their own internship and are interviewed afterwards. The qualitative study shows a variety of facets in the 'learning space business internship'. In this context, attention is also directed to a phenomenon which is described as 'opening the learning space'. The article ends with an 'opening tableau' showing the different tasks of schools, companies and the individual learners in this regard.

Keywords: opening learning spaces, business internship, workplace mentoring, connectivity

Business internships as a supplemental learning space in vocational fulltime schools

The initial hypothesis of the research project reported in this article is that business internships can be interpreted as learning spaces that can be used for individual competence development in a professional domain. The term 'learning space' in our work is based upon social constructivist learning theory. Learning is interpreted as an individual process mediated by tools and rooted in a social context. This understanding stems from the activity theory (Vygotsky 1978: 40), a perspective 
that was further elaborated by Lave \& Wenger (1991: 29) who interpreted learning as 'situated activity'. Stressed in this regard is also the relational feature of learning. 'This view also claims that learning, thinking, and knowing are relations among people in activity in, with, and arising from the socially and culturally structured world.' (Lave \& Wenger 1991: 51)

Internships can be interpreted as a specific form of 'legitimate peripheral participation in a community of practice' (Ostendorf 2007). This also clarifies that these learning spaces cannot be seen as static containers. They are constructed in reflection and action, which learners develop and use simultaneously. Learning spaces emerge as a relational phenomenon constituted by persons, contents, tools (including language), organisational structures and cultural patterns. They are spaces for experiences and reflection is required to construct competencies (Wittwer \& Dittrich 2015: 20, see also Kersh \& Evans in this paper collection).

The PEARL project ('interns investigate their working and learning') ${ }^{8}$ focuses on the facets of this learning space established to deepen the pupils' work-related experiences and their vocational competence development.

Internships can be characterised in different dimensions and the term 'internship' is multi-faceted in its use and meaning. Maertz, Stoeberl and Marks (2014: 125) worked out $11 \mathrm{key}$ dimensions in this regard. The following table shows the dimensions and the specific features of the PEARL internships. Business internships are part of the curriculum of all higher and medium vocational schools at the secondary level in Austria.

${ }^{8}$ PEARL (in German: Praktikanten/innen erforschen ihr Arbeiten und Lernen) is funded by the Austrian Ministry of Economics, Research and Science within the Sparkling Science program from 2015-2017 and is conducted by the business education unit at the University of Innsbruck, Austria. For details see https://www.uibk.ac.at/projects/pearl/projektbeschreibung.html.en 


\begin{tabular}{|l|l|}
\hline Dimension & PEARL internship characteristics \\
\hline Payment & Payed \\
\hline Working hours & $\begin{array}{l}8-12 \text { weeks, 40 hours per week, mostly during summer } \\
\text { holidays partly overlapping with four weeks in school. }\end{array}$ \\
\hline Institutional context & $\begin{array}{l}\text { Internship are a part of the curriculum of colleges of } \\
\text { higher vocational education (secondary level, 17-19 } \\
\text { years old) } \\
\text { Branches: tourism, trade/administration and technical }\end{array}$ \\
\hline Evaluation modus & Marked by the school \\
\hline Academic requirements & $\begin{array}{l}\text { Low academic requirements, i.e. learning on-the-job and } \\
\text { ad hoc instruction; specific in PEARL: logbooks. }\end{array}$ \\
\hline Arrangement parties & $\begin{array}{l}\text { Learners look for internship workplaces for themselves, } \\
\text { only partly assisted by the school }\end{array}$ \\
\hline Transparency of duties & $\begin{array}{l}\text { The internship has to follow the very general regulations } \\
\text { of the curriculum, i.e. related to specific branches and } \\
\text { working tasks and legal requirements. No specific } \\
\text { restrictions for employers besides legal frameworks (as } \\
\text { youth protection law), in particular, no requirements } \\
\text { concerning concrete working contents. }\end{array}$ \\
\hline Work format & Usually job-based format, sometimes related to projects \\
\hline Faculty sponsor/mentor & Part of the teachers' work, not regulated \\
\hline Work sponsor/mentor & $\begin{array}{l}\text { Usually official contact person and informal mentors at } \\
\text { the workplace }\end{array}$ \\
\hline Future employment aspects & $\begin{array}{l}\text { No implications regarding following full-time } \\
\text { employment but career orientation as a general goal }\end{array}$ \\
\hline
\end{tabular}

Table 1: PEARL Internship Characteristics

\section{The empirical design of PEARL}

The internships are investigated in PEARL from the interns' perspectives. A very specific feature in the PEARL project is that pupils get involved as co-researchers in the qualitative research study. They are not objects of research but partners in setting up the research plan, collecting data in their workplaces during work, and interpreting the first draft of the analysis. The working contexts of the interns vary, ranging from tourism, to administration, to technical placements.

In total, 59 pupils, approximately 17-19 year old, from two colleges of higher vocational education (grade IV, ISCED 5) were involved in four ways:

i. They received training in qualitative research methods in different workshops at school and university and made their own 'research plans' for their internships; 
ii. They acted as auto-ethnographic junior researchers during their internships in summer 2015, documenting learning events, occasions and situations with the help of a prepared logbook. Students also took photos of persons and materials which, from their perspective, helped them learn. Thus, to some extent, the autophotography method (Kolb 2012) was used as an additional tool for investigation.

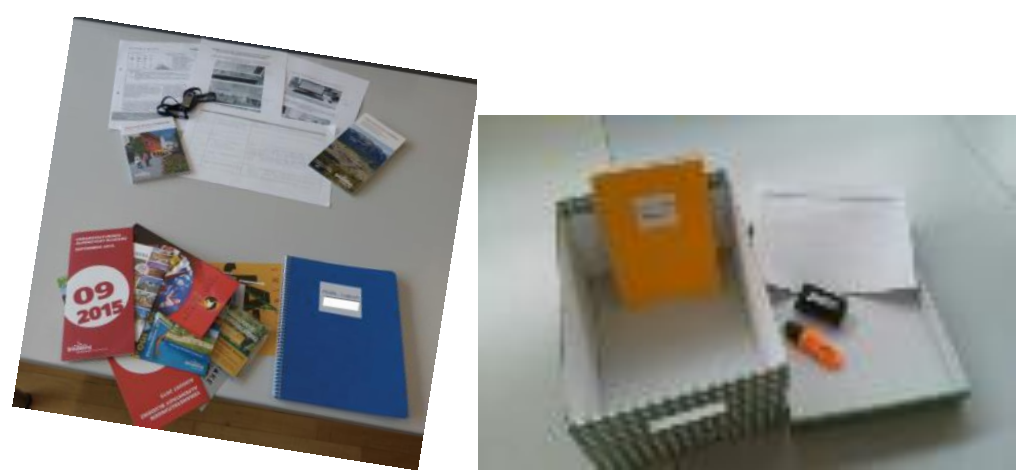

iii. In qualitative interviews, they explained their experiences and all the collected items; and, finally,

iv. Some pupils cross-validated our coding of the data, giving us feedback on our first interpretations.

In PEARL, each intern's internship learning experiences are regarded as a 'case', including data from the stimulated recall interview, the logbook, the photos and other materials.

The analysis follows the design of grounded theory in the pragmatic version of Strauss and Corbin (1996). It is not yet finished, but we made different rounds of coding, which included four researchers. In addition, we conducted a crossvalidation after the first round of coding with the pupils of one partner school to see the level of interpretation conformity. The results show a high rate of consensus.

\section{Facets of the 'learning space business internship'}

In our first coding, we could identify at least three main facets of the learning space: the content-related, the social and the personal (Ostendorf 2016). For illustration purposes, some aspects of these facets are described in more detail below. 


\section{The content-related learning space facet}

Interns see content-related learning, in particular 'new contents', as important but not in the foreground. Of course, they learn about new tools, products and procedures; however, in PEARL, the interns are already quite experienced in their vocations. The internship, therefore, is not their first practical work experience. Interestingly, in the gastronomic internships, the aesthetic dimension played a dominant role in the content-related learning space facet. Many photos collected as representative of the learning activities showed elegantly laid tables, nicely arranged buffets, and beautifully decorated dining areas or food. One problem in relation to content-related learning was that the interns' competencies were partly underestimated by the employers, particularly in internships in foreign

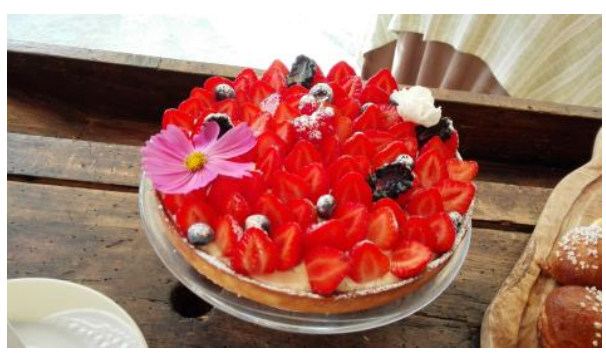
countries. The employers did not know anything about the pupils' type of school and the quality of vocational learning there.

“(...) particularly in the beginning when they do not know what you really can do. They think, you haven't been anywhere. So, on the first day, they tried to teach me how to carry plates (...)." (case 8:158)

However, especially in intercultural internships, unknown foods, beverages, service procedures, foreign languages and intercultural encounters with guests and colleagues formed a very rich learning space not only in content-related aspects but also in social dimensions. Also, special events, such as golf tournaments, weddings, and festivals, presented outstanding experiences to the interns.

\section{The social learning space facet}

Living in another place or even another country meant that the interns had to show the ability to self-organise and to learn how to communicate and interact with different colleagues and clients. Social interactions are a very important aspect of the learning space for the interns. Particularly in this regard, interns are also dependent on the learning environment and the opening of learning spaces. In administrative and technical internships, the processes of 'explaining', 'showing' and 'observing' were very important in relation to a more peripheral position in a 
community of practice, whereas in gastronomic work experiences, the intern was often a full member of the community of practice and a part of the working team.

\section{The personal learning space facet}

Internships offer many opportunities to learn something about one's self, mental state, emotional stability and the ability to handle crises ('difficult' clients, conflicts with colleagues, etc.). Feedback processes play an important role in personal learning spaces. They provide reasons to reflect on the development of the self, career options and the work-life balance.

“(...) but I was in an area which I liked very much and I also got the feedback of my mentor, that I have done this really well and show great motivation - and, yes, then I thought that I could do this also after finishing school because you don't really know what to do after school." (case 21: 97)

\section{Opening the learning space}

Whether the learning space is used or not depends on the interns themselves, but also on the opening of them by more experienced colleagues and groups. We found this 'opening phenomenon' in the empirical data in different forms. Learning happens also en passant, informally, implicitly, but it is often linked to experienced others and working conditions. In our empirical data, we could only analyse reflected learning, either in the logbook or in the interview or photo material. Meaning has to be given to it. Without reclaiming a philosophy of meaning (see, e.g., Speaks 2016), it should be stated that, in our context, giving meaning is bound to a constructivist view. This implies that 'meaning' is constructed by the individual learner in a motivated, active reflection process of concrete experiences.

To give something a meaning is the first step towards opening oneself to a new experience, of offering learning opportunities, and of supporting the learning process in different ways. The 'giving meaning' or 'opening' process can be activated by persons and institutional settings.

We will see that there is more than one dimension of opening the learning space, but in the beginning, we focus on the mentoring processes. 


\section{Opening dimension: Workplace mentoring}

With a view on the current status of data analysis in the Sparkling Science PEARL Project, it becomes clear that one of the most fundamental push factors for fostering learning and development processes of interns is workplace mentoring. This reaffirms the findings of former theoretical and empirical research characterising the special role of formal and informal workplace facilitators (Billett 2001, 2004; Illeris 2011; Ostendorf 2012, 2014). Perhaps that is not very surprising, but there is not a lot of knowledge on the processes, practices and (organisational) structures of these facilitation phenomena. Additionally, even in research literature, the phenomenon of facilitation or supporting learning in the workplace is not stated clearly. Some very prominent terms for this phenomenon are mentoring or guidance, which are overlapping concepts. Our preference for the PEARL project is to use the term 'mentoring', because in business internships, competence development/identity building and career themes are linked, and both can be fostered in a more formal or informal way and encompass dyadic and multiple relationships. Guidance as a more knowledge-focused term is included in our definition of mentoring: Workplace mentoring can be defined as a process of facilitation and guidance, including knowledge transformation and social integration in teams and communities of practice. It is offered by experienced persons and addressed to novices or less experienced colleagues in the occupational field.

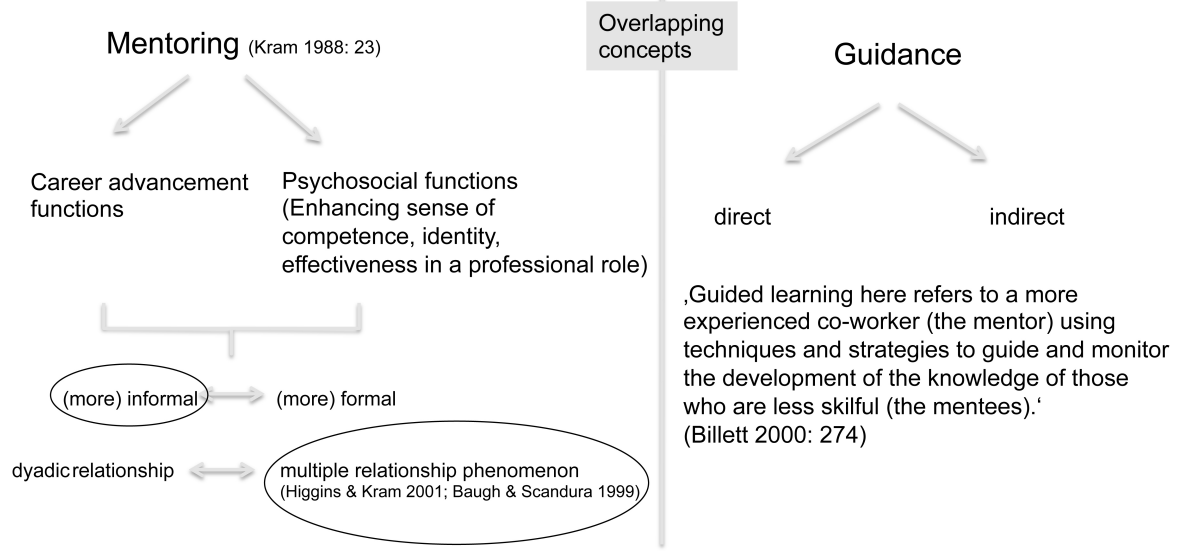

Figure 1: Mentoring and guidance. 
PEARL results show a differentiated picture of workplace mentoring within internships that should be consolidated and may be further developed to other contexts of workplace mentoring to gain a more sophisticated theory of these processes.

To focus on the contribution of mentoring processes to the usage and development of learning spaces, we extracted some of our data and made a representative (related to all cases) sub-sample, which included six 'cases'.

\begin{tabular}{lll} 
Business context & $\begin{array}{l}\text { Overall impression rather } \\
\text { positive }\end{array}$ & $\begin{array}{l}\text { Overall impression rather } \\
\text { negative }\end{array}$ \\
\hline $\begin{array}{l}\text { Administration } \\
\text { Technical }\end{array}$ & $\begin{array}{l}\text { case } 21, \mathrm{~m}, \mathrm{SE} \\
\text { case } 50, \mathrm{~m}, \mathrm{LE}\end{array}$ \\
$\begin{array}{l}\text { Tourism } \\
\text { Service }\end{array}$ & $\begin{array}{l}\text { case 2, } \mathrm{f}, \mathrm{SE} \\
\text { case 37, f, SE }\end{array}$ & case 38, f, SE \\
$\begin{array}{l}\text { Tourism } \\
\text { Cooking }\end{array}$ & case 13, $\mathrm{m}, \mathrm{SE}$, abroad & \\
\hline
\end{tabular}

Table 2: Sampling, LE = Large Enterprises ( $>250$ employees), SE = Small Enterprises (1-49 employees)

For this special analysis, the following was the leading research question:

How can we develop a deeper understanding of learning in business internships and the meaning of formal and informal mentoring processes

The interns reported different experiences with workplace mentoring in their internship. Many types of mentoring could be identified, including formal and informal, intensive or loosely coupled, changing or evolving, and as a one-person task or network bound.

In many cases, it became clear that internship mentoring is not only a task for a single person formally or informally assigned to supervise the novices at the workplace. Different persons in different settings are involved.

"They explained everything to me and made sure that they only explained it and not that everyone just did something, so that I understood it better." (case 2, 84) 
Some mentors are more engaged in knowledge transfer, others in caring, some are officially designated to look after the interns, and others do it informally at the workplace, near the workplace or in private settings. Thus, the phenomenon of internship mentoring is multifaceted and complex.

Therefore, the focus of research also has to be directed to the communities of practices (CoP) (Wenger 1998) and the network structures. CoP differ in kind and scope and are not expected to automatically welcome the newcomer. That would be too idealistic. However, a certain degree of the CoP's willingness to integrate the novice can be seen as a precondition for internships offering learning spaces.

"I did have the feeling that I was now part of a team and definitely a different feeling than in previous internships." (case 17, 107)

In the cases, we saw different types of mentoring, some strongly protective, others with a high grade of laissez-faire. However, a minimum of protection is needed to discharge educational duties against young vulnerable people. This shows in the following quotation:

"And so I had to be there at 12. Normally, work started at half past three, but there at 12 and even then until one or one thirty when I went home, and it was quite a shock to start with and I thought, you can't do that with an intern, but somehow it just didn't interest anybody." (case 38, 59)

The protection task of $\mathrm{CoP}$ at the workplace differs according to the age and experience of the intern. Still, all are newcomers and, in terms of power relations at the workplace, underprivileged. Displaying and explaining (besides the delegation of tasks) are given priority, especially within administrative and technical internships; in tourism internships, the integration in the team is given more weight.

Companies offering internships can support the usage of learning spaces at the workplace by carefully informing and establishing the mentoring infrastructure. This includes information about the type of school, curricula requirements and recognising the interns' previous knowledge. During the working phases, the companies have to offer to some extent caring and learning opportunities, and if possible, job rotation. They should be aware of their responsibility in the vocational education process and open themselves up for and take part in evaluations.

The data in PEARL show that workplace mentoring is a very important issue for opening the learning spaces in business internships. However, we also found other dimensions of opening the learning spaces and assuring quality in internship learning. Also, the delegating school and the intern herself/himself have to fulfil a kind of 'opening' to secure the usage of workplace learning spaces. 


\section{Opening dimension: The learner}

The 'opening' of the individual learner herself/himself means that the learner should be able and willing to look for and reflect on new experiences. This can be supported by tools, such as logbooks (as used in PEARL for reflection and research purposes) or learning portfolios. (Dimai/Hautz 2016). The logbook helped the interns to give their experiences meaning.

"(...) one is (using the logbook, A. O.) a little bit more reflective because we would not think about this now: have I learned something or so? (...) After this, one goes with other expectations into the internship, as you realise this as a learning process." (case 50,672)

"Actually, I must say that in writing down this and getting rid of my thoughts, putting them behind me (...), in some way I could deal with it better." (case 31,488 )

The PEARL logbook had a two-fold function - it was used as a documentation and reflection tool and it was research equipment. In giving the logbook the second function as a research tool, some of the students viewed the task of documenting and reflecting in a different way:

"Therefore, I felt like a researcher, and by the way, we never had such a cool logbook before, where we could fix issues we realised, or something we were told was well done. And the mind-map - when we make our internship folder... the teacher never looked at it so intensively." (case 42: 646)

This spirit could perhaps be more intensively implemented also in the traditional usage of logbooks or similar tools.

\section{Opening dimension: Tasks of the school}

An appropriate collaborative preparation of reflecting tools in schools would be helpful. This was done in the case of PEARL by the researchers of Innsbruck University partly together with the interns (research plan), but this could also be done by teachers and pupils in school as preparatory work temporarily before the internship. 
The interns were also asked as quasi-experts to explain whether and where the school could and should support the internship. An often-mentioned aspect was to set standards for quality and make information on former interns' experiences available for the next generation of interns.

The school has to show commitment to the internships. Its role in opening learning spaces is particularly important before and after the internship. During the working phase, they only have a peripheral role (motivation and, perhaps, support in emergencies). However, during the preparation phase, they can initiate the reflective attitude and motivation, prepare tools for reflection, and frame the quality of internships by defining selection standards for workplaces. In a connective way that covers the experiences of the two learning sites (school and the workplace), teachers can foster cross-border learning also after the internship. There should also be an openness concerning new knowledge derived from the internship experience, which could, perhaps, be used in classroom work or training workshops at school.

\section{The 'opening tableau'}

The differentiation between various dimensions should not conceal that the opening of the learning space business internship needs a connective perspective on workplace learning. All three dimensions are connected and, in conjunction, establish a network that enables competence development. As a theoretical framework, connectivity theory as elaborated by Griffith and Guile (2003) or Tynjälä (2010) may serve as a suitable theoretical background. Against this background, we set up the following 'opening tableau', showing different opening dimensions (including responsibilities) and phases (related to the internship). The opening of learning spaces refers to individual learners, schools and companies. All have different but connected tasks before, during and after the internship experience. 
Opening learning spaces for business interns

\begin{tabular}{|c|c|c|c|}
\hline $\begin{array}{l}\text { Phases of internship } \\
\text { Opening dimension }\end{array}$ & pre & during & post \\
\hline Individual learner & $\begin{array}{l}\text { Careful selection of } \\
\text { internship positions related to } \\
\text { own learning interests. } \\
\text { Preparing reflective tools } \\
\text { (such as logbooks). }\end{array}$ & $\begin{array}{l}\text { Continuously reflecting } \\
\text { and documenting the } \\
\text { learning experiences, } \\
\text { special events, new } \\
\text { insights }\end{array}$ & $\begin{array}{l}\text { Comparing and sharing the } \\
\text { reflections with peers and } \\
\text { teachers }\end{array}$ \\
\hline school & $\begin{array}{l}\text { Preparing the logbooks/ } \\
\text { portfolios/other tools together } \\
\text { with the learners } \\
\text { Counselling in the } \\
\text { application phase } \\
\text { Setting quality criteria }\end{array}$ & $\begin{array}{l}\text { Infrastructure for special } \\
\text { needs } \\
\text { Motivate the individual } \\
\text { learners to reflect }\end{array}$ & $\begin{array}{l}\text { Combining work } \\
\text { experiences with subject- } \\
\text { related knowledge } \\
\text { Being open to innovation } \\
\text { coming from the } \\
\text { workplaces }\end{array}$ \\
\hline company & $\begin{array}{l}\text { Organising and information } \\
\text { of the 'network' } \\
\text { Becoming informed about } \\
\text { school curricula and } \\
\text { requirements }\end{array}$ & $\begin{array}{c}\text { Knowledge transfer } \\
\text { forntal Communityoff Practice } \\
\text { Network structure } \\
\text { caring }\end{array}$ & $\begin{array}{l}\text { Supporting school and } \\
\text { interns by giving feedback }\end{array}$ \\
\hline
\end{tabular}

Table 3: The Opening Tableau of Internships as Learning Spaces

\section{Outlook}

In the PEARL project, we could gain insights into interns' learning from the perspective of the concerned learners. Involving them in the project also gave the interns transparency about what it means to do qualitative research in social science. They became familiar with tools and could be a part of the research process. We also recognised from the interview data that it was exactly this circumstance that made the PEARL internship very special for the students. However, we also have to mention that involving pupils - even if they are older ones - into research agendas is challenging. The differences in the living worlds of university researchers and pupils and the balancing act between scientific and everyday language as well as motivational aspects - particularly over many months - are not easily handled. A strong commitment by the teachers is essential, and a lot of translation processes must be organised. In our case, we could establish a very fruitful cooperation which brought advantages to all sides. 


\section{References}

Baugh, S. G., Scandura, T. A. (1999): The Effect of Multiple Mentors on Protege Attitudes Toward the Work Setting, in: Journal of Social Behavior and Personality, 14, 4, pp. 503-521

Billett, S. (2000): Guided learning at work, in: Journal of Workplace Learning, Vol. 12, 7, pp. 272-285.

Billett S. (2001) Learning in the workplace : strategies for effective practice. 1. publ. Crows Nest, NSW: Allen \& Unwin.

Billett S. (2004) Learning through work. Workplace participatory practices, in: Rainbird, H./Fuller, A./Munro, A. (Eds.), Workplace Learning in Context, pp. 109-125, London: Routledge.

Dimai, B., Hautz, H. (2016): Das Logbook als Lern - und Forschungsinstrument im Betriebspraktikum - Potenziale und Herausforderungen, in: wissenplus, Sonderausgabe Wissenschaft, S. 59-62.

Griffiths, T./Guile, D. (2003). A Connective Model of Learning: the implications for work process knowledge. European Educational Research Journal, Vol. 2:1, 5673.

Higgins, M. C., Kram, K. E. (2001): Reconceptualizing Mentoring at Work: A Developmental Network Perspective, in: The Academy of Management Review, Vol. 26, No. 2, pp. 264-288.

Illeris K. (2011): The fundamentals of workplace learning: understanding how people learn in working life. 1. ed. London ua: Routledge.

Kolb, B. (2012): Unveiling Space by using Participatory Photo Interview, in: Silva, C. (Ed.) Online Research Methods in Urban and Planning Studies: Design and Outcomes. IGI-Global, pp. 120-137.

Kram, K. E. (1988): Mentoring at work. Developmental Relationships in Organizational Life, Lanham: University Press of America.

Lave, J./Wenger, E. (1991): Situated learning. Legitimate peripheral participation, Cambridge: Cambridge University Press.

Maertz, C. P. Jr. / Philipp, A., Stoeberl J. M. (2014): Building successful internships: lessons from the research for interns, schools and employers, Career Development International, Vol. 19, Issue 1, pp. 123-142

Ostendorf, A. (2012) Informal workplace "educators": The hidden protagonists of workplace learning", in: Decoding the meanings of learning at work in Asia and Europe, pp. 67-76, Innsbruck: Innsbruck University Press.

Ostendorf, A. (2013): Betriebspädagogische Herausforderungen bei der Verbindung von Arbeiten und Lernen im Betriebspraktikum - die Rolle der Praktikumsbetreuer/-innen, in: Niedermair, G. (Hrsg.): Facetten berufs- und 
betriebspädagogischer Forschung. Grundlagen-Herausforderungen-Perspektiven, S. 253-265, Linz: Trauner.

Ostendorf, A. (2014): Aufgabenwahrnehmung und Rolleninterpretation informell oder non-formal betrieblich Lehrender - dargestellt am Beispiel Praktikumsbetreuung, in: Braukmann, U., Dilger, B., Kremer, H.-H. (Hrg.): Wirtschaftspädagogische Handlungsfelder, S. 203-214, Detmold: Eusl.

Ostendorf, A. (2016): Welche Lernräume nutzen BHS Schüler/innen im Betriebspraktikum? - erste Ergebnisse aus dem Sparkling Science Projekt PEARL, in: Wissenplus. Sonderausgabe Wissenschaft, S. 12-16.

Scandura, T. A. \& Pellegrini, E. K. (2010): Workplace Mentoring: Theoretical Approaches and Methodological Issues, in: Allen, T. D. \& Eby, L. T.: The Blackwell Handbook of Mentoring. A multiple perspectives approach, pp.71-91, Oxford: Wiley-Blackwell.

Speaks, J., (2016): "Theories of Meaning", The Stanford Encyclopedia of Philosophy (Spring 2016 Edition), Edward N. Zalta (ed.), URL = $<$ https://plato.stanford.edu/archives/spr2016/entries/meaning/>.

Strauss, A., Corbin, J. (1996) Grounded Theory: Grundlagen Qualitativer Sozialforschung. Weinheim: Beltz.

Tynjälä, P. (2010): Connectivity and Transformation in Work-Related Learning Theoretical Foundations, in: Stenström, M.-L./Tynjälä, P. (Eds.): Towards Integration of Work and Learning. Strategies for Connectivity and Transformation: Springer, pp. 11-37.

Vygotsky, L. S. (1978): Mind in Society. The Development of Higher Psychological Processes: Harvard University Press.

Wenger, E. (1998): Communities of Practice: Learning, meaning and identity, New York: Cambridge University Press. 